\title{
Genetic associations of vitamin D receptor polymorphisms with advanced liver fibrosis and response to pegylated interferon-based therapy in chronic hepatitis $\mathbf{C}$
}

\author{
Kessarin Thanapirom ${ }^{1,2}$, Sirinporn Suksawatamnuay ${ }^{1,2}$, Wattana Sukeepaisarnjaroen ${ }^{3}$, Pisit Tangkijvanich ${ }^{4}$, \\ Panarat Thaimai ${ }^{1,2}{ }^{\text {, Rujipat Wasitthankasem }}{ }^{5}$, Yong Poovorawan ${ }^{5}$, Piyawat Komolmit ${ }^{\text {Corresp. } 1,2}$ \\ ${ }^{1}$ Department of Medicine, Faculty of Medicine, Chulalongkorn University and King Chulalongkorn Memorial Hospital, Thai Red Cross Society, Divisions of \\ Gastroenterology and Hepatology, Bangkok, Thailand \\ 2 Chulalongkorn University, Liver Fibrosis and Cirrhosis Research Unit, Bangkok, Thailand \\ 3 Department of Medicine, Srinagarind Hospital, Faculty of Medicine, Khon Kaen University, Gastroenterology unit, Khon Kaen, Thailand \\ 4 Faculty of Medicine, Chulalongkorn University, Department of Biochemistry, Bangkok, Thailand \\ 5 Department of Pediatrics, Faculty of Medicine, Chulalongkorn University, Center of Excellence in Clinical Virology, Bangkok, Thailand \\ Corresponding Author: Piyawat Komolmit \\ Email address: pkomolmit@yahoo.co.uk
}

Vitamin D receptor (VDR) modulates host immune responses to infections such as hepatitis $C$ virus (HCV) infection, including interferon signaling. This study aimed to investigate the associations of VDR polymorphisms with advanced liver fibrosis and response to pegylated interferon (PEG-IFN)-based therapy in patients with chronic HCV infection. In total, 554 Thai patients with chronic HCV infection treated with a PEG-IFN-based regimen were enrolled. Six single-nucleotide polymorphisms (SNPs) were genotyped: the IL28B C>T (rs12979860) SNP and five VDR SNPs, comprising Fokl T>C (rs2228570), Bsml C>T (rs1544410), Tru9l G>A (rs757343), Apal C>A (rs7975232), and Taql A>G (rs731236). In total, 334 patients (60.3\%) achieved sustained virological response (SVR), and 255 patients (46\%) were infected with HCV genotype 1 . The bAt (CCA) haplotype, consisting of the Bsml rs1544410 C, Apal rs7975232 C, and Taql rs731236 A alleles, was associated with poor response (in terms of lack of an SVR) to PEG-IFN-based therapy. The IL28B rs12979860 CT/TT genotypes ( $\mathrm{OR}=3.44,95 \% \mathrm{Cl}: 2.12-5.58, \mathrm{p}<0.001$ ), bAt haplotype $(\mathrm{OR}=2.02,95 \% \mathrm{Cl}: 1.04-3.91, \mathrm{p}=0.03)$, pre-treatment serum HCV RNA (loglU/ml; OR=1.73, $95 \% \mathrm{Cl}: 1.31-2.28, \mathrm{p}<0.001$ ), advanced liver fibrosis ( $\mathrm{OR}=1.68,95 \% \mathrm{Cl}: 1.10-2.58, \mathrm{p}=0.02$ ), and HCV genotype $1(\mathrm{OR}=1.59,95 \% \mathrm{Cl}: 1.07-2.37, \mathrm{p}=0.02)$ independently predicted poor response. Patients with the bAt haplotype were more likely to have poor response compared to patients with other haplotypes ( $41.4 \%$ vs $21.9 \%, p=0.03)$. The Fokl rs2228570 TT/TC genotypes ( $O R=1.63,95 \% \mathrm{Cl} 1.06-2.51, \mathrm{p}=0.03)$ and age $\geq 55$ years $(\mathrm{OR}=2.25 ; 95 \% \mathrm{Cl}: 1.54-3.32, \mathrm{p}<0.001)$ were independently associated with advanced liver fibrosis, assessed based on FIB-4 score $>3.25$. VDR polymorphisms were not associated 
with pre-treatment serum HCV RNA. In Thai patients with chronic HCV infection, the bAt haplotype is associated with poor response to PEG-IFN-based therapy, and the FokI rs2228570 TT/TC genotypes are risk factors for advanced liver fibrosis. 


\section{Genetic Associations of Vitamin D Receptor Polymorphisms}

2 with Advanced Liver Fibrosis and Response to Pegylated 3 Interferon-based Therapy in Chronic Hepatitis $\mathbf{C}$

4 Kessarin Thanapirom ${ }^{1,2}$, Sirinporn Suksawatamnuay ${ }^{1,2}$, Wattana Sukeepaisarnjaroen ${ }^{3}$, Pisit

5 Tangkijvanich ${ }^{4}$, Panarat Thaimai ${ }^{1,2}$, Rujipat Wasitthankasem ${ }^{5}$, Yong Poovorawan ${ }^{5}$, Piyawat 6 Komolmit $^{1,2}$

$7 \quad{ }^{1}$ Division of Gastroenterology and Hepatology, Department of Medicine, Faculty of Medicine,

8 Chulalongkorn University and King Chulalongkorn Memorial Hospital, Thai Red Cross Society,

9 Bangkok, Thailand

$10{ }^{2}$ Liver Fibrosis and Cirrhosis Research Unit, Chulalongkorn University, Bangkok, Thailand

$11{ }^{3}$ Gastroenterology Unit, Department of Medicine, Srinagarind Hospital, Faculty of Medicine, 12 Khon Kaen University, Khon Kaen, Thailand

134 Department of Biochemistry, Faculty of Medicine, Chulalongkorn University, Bangkok, 14 Thailand

$15{ }^{5}$ Center of Excellence in Clinical Virology, Department of Pediatrics, Faculty of Medicine, 16 Chulalongkorn University, Bangkok, Thailand

Corresponding author:

Assoc. Prof. Piyawat Komolmit, MD, Ph.D.

Division of Gastroenterology and Hepatology, Department of Medicine,

Faculty of Medicine, Chulalongkorn University

Rama 4 Road, Pathumwan District,

Bangkok 10330, Thailand

Tel: +66-2-256-4265, Fax: +66-2-252-7839 


\section{ABSTRACT}

Vitamin D receptor (VDR) modulates host immune responses to infections such as hepatitis $\mathrm{C}$ virus (HCV) infection, including interferon signaling. This study aimed to investigate the associations of $V D R$ polymorphisms with advanced liver fibrosis and response to pegylated interferon (PEG-IFN)-based therapy in patients with chronic HCV infection. In total, 554 Thai patients with chronic $\mathrm{HCV}$ infection treated with a PEG-IFN-based regimen were enrolled. Six single-nucleotide polymorphisms (SNPs) were genotyped: the $I L 28 B \mathrm{C}>\mathrm{T}$ (rs12979860) SNP and five VDR SNPs, comprising FokI $\mathrm{T}>\mathrm{C}$ (rs2228570), BsmI C $>\mathrm{T}$ (rs1544410), Tru9I G $>\mathrm{A}$ (rs757343), ApaI C $>\mathrm{A}$ (rs7975232), and TaqI A $>\mathrm{G}$ (rs731236). In total, 334 patients (60.3\%) achieved sustained virological response (SVR), and 255 patients (46\%) were infected with HCV genotype 1. The bAt (CCA) haplotype, consisting of the BsmI rs1544410 C, ApaI rs7975232 C, and TaqI rs731236 A alleles, was associated with poor response (in terms of lack of an SVR) to PEG-IFN-based therapy. The IL28B rs $12979860 \mathrm{CT} / \mathrm{TT}$ genotypes (OR=3.44, 95\%CI: $2.12-5.58$, $\mathrm{p}<0.001)$, bAt haplotype $(\mathrm{OR}=2.02,95 \% \mathrm{CI}: 1.04-3.91, \mathrm{p}=0.03)$, pre-treatment serum HCV RNA $(\operatorname{logIU} / \mathrm{ml}$; OR $=1.73,95 \% \mathrm{CI}: 1.31-2.28, \mathrm{p}<0.001)$, advanced liver fibrosis $(\mathrm{OR}=1.68,95 \% \mathrm{CI}$ : $1.10-2.58, \mathrm{p}=0.02)$, and $\mathrm{HCV}$ genotype $1(\mathrm{OR}=1.59,95 \% \mathrm{CI}: 1.07-2.37, \mathrm{p}=0.02)$ independently predicted poor response. Patients with the bAt haplotype were more likely to have poor response compared to patients with other haplotypes ( $41.4 \%$ vs $21.9 \%$, $\mathrm{p}=0.03)$. The FokI rs 2228570 TT/TC genotypes $(\mathrm{OR}=1.63,95 \% \mathrm{CI} 1.06-2.51, \mathrm{p}=0.03)$ and age $\geq 55$ years $(\mathrm{OR}=2.25 ; 95 \% \mathrm{CI}: 1.54$ $3.32, \mathrm{p}<0.001)$ were independently associated with advanced liver fibrosis, assessed based on FIB4 score $>3.25$. VDR polymorphisms were not associated with pre-treatment serum HCV RNA. In Thai patients with chronic HCV infection, the bAt haplotype is associated with poor response to PEG-IFN-based therapy, and the FokI rs2228570 TT/TC genotypes are risk factors for advanced liver fibrosis.

Subjects Genetics, Gastroenterology and Hepatology, Translational Medicine

Key words Vitamin D receptor polymorphisms, hepatitis C virus, pegylated interferon, advanced liver fibrosis 
64

65

66

67

68

69

70

71

72

73

74

75

76

77

78

79

80

81

82

83

84

85

86

87

88

89

90

91

92

93

94

95

96

97

98

99

100

101

102

103

104

\section{INTRODUCTION}

Hepatitis $\mathrm{C}$ virus (HCV) infection is a major health problem affecting $>71.1$ million people worldwide, leading to chronic hepatitis, liver cirrhosis, and hepatocellular carcinoma (HCC)(WHO 2017). The advancement of HCV treatment in terms of the development of directacting antiviral agents (DAAs) has evoked international interest in the global elimination of HCV. In 2017, the World Health Organization set targets to eliminate viral hepatitis as a public threat worldwide by 2030 by achieving a $90 \%$ diagnosis rate, an $80 \%$ treatment rate, and a $65 \%$ reduction in the mortality rate. In patients with chronic HCV, the new DAAs can achieve a sustained virological response (SVR) rate $>90 \%$. International guidelines e.g., the 2018 European Association for the Study of the Liver (EASL) and 2018 American Association for the Study of Liver Diseases (AASLD) guidelines recommend DAAs as the first-line treatment. The role of pegylated interferon (PEG-IFN) plus ribavirin has continued to diminish. However, up to $80 \%$ of the global HCV burden resides in low- and middle-income countries, including those in Southeast Asia, the Middle East, and North Africa. Due to the high cost and the lack of availability of DAAs, PEG-IFN-based therapy remains the treatment of choice in these countries (Jayasekera et al. 2014; Mohd Hanafiah et al. 2013; Zoulim et al. 2015). The current Asian Pacific Association for the Study of the Liver (APASL) guidelines on the treatment of HCV infection continue to recommend PEG-IFN and ribavirin as first-line therapy in resource-limited countries where DAAs are unavailable (Omata et al. 2016).

Current evidence shows that in addition to playing roles in supporting calcium absorption and bone metabolism, vitamin D (VD) plays several important roles in immunomodulation, regulation of cellular proliferation, differentiation, and apoptosis (Holick 2007; Penna et al. 2005; von Essen et al. 2010). Several studies have reported associations between VD deficiency and risk of cancer, congestive heart failure, insulin resistance, and autoimmune diseases (Feskanich et al. 2004; Giovannucci et al. 2006; Munger et al. 2006). The liver is a crucial organ in VD synthesis as it is the site of the enzymatic conversion of the inactive form of VD to 25-dihydroxyVD. VD deficiency was found in $70 \%$ of patients with chronic liver disease regardless of the etiology, and $22 \%$ had severe VD deficiency (Arteh et al. 2010). Patients with chronic HCV infection had lower serum VD levels than sex- and age-matched healthy controls (Petta et al. 2010). In terms of clinical outcomes, low VD level has been reported to be independently related to advanced liver fibrosis and high necroinflammatory activity in chronic HCV patients (Dadabhai et al. 2017; Petta et al. 2010). Two large meta-analyses reported a negative association between VD level and SVR in chronic HCV patients treated with PEG-IFN therapy (Garcia-Alvarez et al. 2014; Villar et al. 2013).

Vitamin D receptor (VDR) is a nuclear hormone receptor that can act as a ligand-induced transcription factor. VDR binds to the active form of VD and thereby mediates its effect (Keane et al. 2018). The receptor is encoded by the $V D R$ gene, which is located on chromosome 12q. The gene has a promoter, regulatory regions, and exons 2-9, which span over $100 \mathrm{~kb}$ (Deeb et al. 2007; Uitterlinden et al. 2004). Using different restriction endonucleases for the BsmI, Tru9I, ApaI, and TaqI sites (to cleave the DNA at the 3' end) and FokI (to cleave the DNA in exon 2), multiple VDR polymorphisms have been explored (Uitterlinden et al. 2004). The bAt (CCA) haplotype is a

Peer) reviewing PDF | (2019:04:37052:1:1:NEW 26 Jul 2019) 
common genetic variant of the VDR gene, comprising the following three polymorphisms at the $3^{\prime}$ end of the gene: BsmI rs1544410 C, ApaI rs 7975232 C, and TaqI rs731236 A, which are in strong linkage disequilibrium. Recent research shows that $V D R$ genetic variations lead to susceptibility and chronicity regarding HCV infection (Wu et al. 2016). In addition, $V D R$ polymorphisms may be related to the response to PEG-IFN and ribavirin therapy in chronic HCV patients. However there have been conflicting results regarding these relationships in previous studies (Baur et al. 2012b; Garcia-Martin et al. 2013; Hung et al. 2016; Shaker et al. 2016). This study aims to investigate whether the common $V D R$ polymorphisms are associated with the response to PEGIFN-based therapy and advanced liver fibrosis in patients with chronic HCV infection.

\section{MATERIALS \& METHODS}

\section{Patients}

This study included Thai patients with chronic HCV infection at Chulalongkorn University hospital (Bangkok, Thailand) and Srinagarind hospital (Khon Kaen, Thailand) from June 2012 to December 2013. All patients had positive anti-HCV antibody and detectable HCV RNA. They were treated with PEG-IFN and ribavirin based on standard recommendations (European Association for the Study of the 2011; Ghany et al. 2009). The exclusion criteria were co-infection with hepatitis B virus or human immunodeficiency virus, decompensated cirrhosis, or prior liver transplantation. Baseline characteristics were recorded, and biochemical and virological tests were conducted at baseline, during treatment and at 24 weeks after treatment. Alcohol consumption was defined as at least 3 standard drinks per week. The Fibrosis-4 (FIB-4) score (based on age, aspartate and alanine aminotransferase levels, and platelet count) was used to assess liver fibrosis. Advanced liver fibrosis was defined as FIB-4 score $>3.25$ (Vallet-Pichard et al. 2007).

The study followed the principles of the Declaration of Helsinki and was approved by the local Institutional Review Board (IRB) committee of the Faculty of Medicine, Chulalongkorn University (IRB number 562/54) and Khon Kaen University (HE561177). Written informed consent was obtained from each participant.

\section{Virological testing}

The quantitative serum HCV RNA level was evaluated using the real-time polymerase chain reaction (RT-PCR) COBAS ${ }^{\circledR}$ Taqman $^{\circledR} \mathrm{HCV}$ test (Roche Diagnostics, Basel, Switzerland). $\mathrm{HCV}$ genotyping was performed using the INNO-LiPA HCV II assay (Innogenetics, Ghent, Belgium).

\section{Genotyping}

Genotyping of the following six single-nucleotide polymorphisms (SNPs) was performed: the interleukin 28B (IL28B; also known as interferon lambda 3 [IFN13]) C $>$ T (rs12979860) SNP and five VDR SNPs, comprising FokI T $>\mathrm{C}$ (rs2228570), BsmI C $>\mathrm{T}$ (rs1544410), Tru9I G $>\mathrm{A}$ (rs757343), ApaI C $>$ A (rs7975232), and TaqI A $>$ G (rs731236). DNA was extracted from $100 \mu \mathrm{L}$ of peripheral blood leukocytes using a standard phenol-chloroform protocol and then kept at $80^{\circ} \mathrm{C}$. Next, $2 \mu \mathrm{L}$ DNA was subjected to PCR (total volume, $25 \mu \mathrm{L}$ ) using Perfect Taq Plus 
143

144

145

146

147

148

149

150

151

152

153

154

155

156

157

158

159

160

161

162

163

164

165

166

167

168

169

170

171

172

173

174

175

176

177

178

179

180

MasterMix (5 PRIME GmbH, Hamburg, Germany). The PCR-specific probes and conditions are summarized in Supplementary Table 1. To assess the IL28B SNP, a sequencing method was used (First BASE Laboratories, Selangor, Malaysia). To assess the five VDR SNPs, restriction fragment length polymorphism (RFLP) assays were conducted. Subsequently, 2\% agarose gel electrophoresis was used to assess the DNA fragments. The separated DNA was viewed under ultraviolet light after staining with ethidium bromide.

Three of the SNPs located at the $3^{\prime}$ end of the VDR gene (BsmI, ApaI, and TaqI) are in strong linkage disequilibrium, and the bAt (CCA) haplotype involves BsmI rs1544410 C, ApaI rs7975232 C, and TaqI rs731236 A.

\section{Statistical analysis}

Statistical analysis was performed using SPSS version 22.0 (IBM Corp., Armonk, NY, USA). Categorical data are expressed as number (percentage), and the differences between groups were compared using the chi-square test. Continuous data are expressed as mean \pm standard deviation, and the differences between groups were compared using Student's t-test and the MannWhitney $U$ test. The effects of pre-treatment factors and the SNPs on the response to PEG-IFNbased therapy (in terms of SVR) and the presence of advanced liver fibrosis were investigated using univariate and stepwise multivariate logistic regression analyses. A $p$-value $<0.05$ was considered statistically significant. The chi-square test was used to verify whether the genotype frequencies related to the SNPs in patients with and without SVR were in accordance with the Hardy-Weinberg assumption.

\section{RESULTS}

\section{Patient characteristics}

A total of 554 Thai patients with chronic HCV infection were enrolled. There were 365 men $(65.9 \%)$ and the mean age was $50.9 \pm 9.2$ years. Three hundred and thirty-four patients (60.3\%) achieved SVR, 255 patients (46\%) were infected with HCV genotype 1, and 176 patients (34.8\%) had advanced liver fibrosis. Table 1 shows the participants' baseline demographic and laboratory data according to treatment response at 24 weeks after PEG-IFN discontinuation. Compared to patients with poor response (in terms of lack of an SVR), patients who achieved SVR were older, had lower pre-treatment serum HCV RNA levels, and were less likely to have HCV genotype 1, advanced liver fibrosis, and the unfavorable IL28B rs12979860 CT/TT genotypes.

Prevalence of VDR polymorphisms and bAt (CCA) haplotype and their associations with response to PEG-IFN-based therapy

The frequencies of the $V D R$ genotypes and the bAt (CCA) haplotype and their associations with response to PEG-IFN-based therapy are shown in Table 2. The genotypic frequencies of the SNPs were in Hardy-Weinberg equilibrium ( $\mathrm{p}>0.05$ ) except for Tru9I (rs757343). The genotypic frequencies of the SNPs were not different between patients with and without SVR.

The FokI, BsmI, Tru9I, ApaI, and TaqI polymorphisms were not associated with response to PEG-IFN-based therapy. However, the bAt (CCA) haplotype was significantly associated with

Peer) reviewing PDF | (2019:04:37052:1:1:NEW 26 Jul 2019) 
181

182

183

184

185

186

187

188

189

190

191

192

193

194

195

196

197

198

199

200

201

202

203

204

205

206

207

208

209

210

211

212

213

214

215

216

217

218

219

poor response to PEG-IFN-based therapy. Overall, $41.4 \%$ of patients with the bAt (CCA) haplotype were poor responders, resulting in an OR of 1.82 (95\% CI: 1.04-3.18, p=0.03) when compared to patients with other haplotypes $(27.9 \%)$.

\section{Factors associated with response to PEG-IFN-based therapy}

Table 3 shows the univariate and multivariate analysis results of the effects of baseline variables on the response to PEG-IFN-based therapy. Based on univariate analysis, advanced age, HCV genotype 1, high pre-treatment HCV RNA level, advanced liver fibrosis, IL28B rs12979860 $\mathrm{CT} / \mathrm{TT}$, and the bAt (CCA) haplotype were significantly associated with poor response to PEGIFN-based therapy. Stepwise multivariate regression analysis showed that the IL28B rs 12979860 $\mathrm{CT} / \mathrm{TT}$ genotypes $(\mathrm{OR}=3.44,95 \% \mathrm{CI}: 2.12-5.58, \mathrm{p}<0.001)$, the bAt (CCA) haplotype (OR=2.02, 95\%CI: 1.04-3.91, p=0.03), pre-treatment HCV RNA level $(\operatorname{logIU} / \mathrm{ml}$; OR=1.73, 95\%CI: $1.31-$ $2.28, \mathrm{p}<0.001)$, advanced liver fibrosis $(\mathrm{OR}=1.68,95 \% \mathrm{CI}: 1.10-2.58, \mathrm{p}=0.02)$, and HCV genotype $1(\mathrm{OR}=1.59,95 \% \mathrm{CI}: 1.07-2.37, \mathrm{p}=0.02)$ were independent baseline predictors of poor response to PEG-IFN-based therapy.

\section{Comparison between bAt (CCA) and other haplotypes}

VDR is expressed in various cell types in the liver, including hepatic stellate cells, Kupffer cells, endothelial cells, and hepatocytes, and upregulated during hepatic injury. It involves in immune regulations. Accordingly, it might affect clinical outcomes of chronic HCV patients treated with PEG-IFN/ribavirin. Several important factors were compared between the chronic HCV patients with bAt (CCA) and other haplotypes to identify the associations with the bAt (CCA) haplotype (Table 4). Among the participants, 486 (87.7\%) had the bAt (CCA) haplotype. There were no differences in pre-treatment HCV RNA level, advanced liver fibrosis, or rapid or early virological response between patients with bAt (CCA) and patients with other haplotypes. However, patients with the bAt (CCA) haplotype were more likely to have unfavorable IL28B rs $12979860 \mathrm{CT} / \mathrm{TT}$ genotypes, and they had lower pre-treatment alanine aminotransferase levels than patients with other haplotypes.

\section{Associations between VDR polymorphisms and both advanced liver fibrosis and HCVRNA level}

Five hundred and six patients $(91.3 \%)$ had pre-treatment laboratory data for calculating FIB-4 score. Of these, 176 patients $(34.8 \%)$ had FIB-4 score $>3.25$ and were thus diagnosed with advanced liver fibrosis. Figure 1 shows the prevalence of advanced liver fibrosis among patients with each $V D R$ genotype. Chronic HCV patients with the FokI rs2228570 TT/TC genotypes (38.6\%) were more likely to have advanced liver fibrosis compared to patients with the CC genotype $(25.8 \%, \mathrm{p}=0.006)$. Pre-treatment HCV RNA level was not significantly different among patients who had different VDR genotypes, as shown in Figure 2.

\section{Factors associated with advanced liver fibrosis}

Univariate and multivariate analysis results for advanced liver fibrosis are shown in Table 5. Based on the univariate analysis, advanced liver fibrosis was associated with age $\geq 55$ years $(\mathrm{p}<0.001)$ and FokI TT/TC genotypes $(\mathrm{p}=0.006)$. Factors with $\mathrm{p}<0.1$ in the univariate analysis were included in the multivariate model. Based on the multivariate analysis, age $\geq 55$ years 
$220(\mathrm{OR}=2.25$; 95\%CI: 1.54-3.32, $<<0.001)$ and FokI TT/TC genotypes $(\mathrm{OR}=1.63$; 95\%CI: 1.06-

221

222

223

224

225

226

227

228

229

230

231

232

233

234

235

236

237

238

239

240

241

242

243

244

245

246

247

248

249

250

251

252

253

254

255

256

257

258

259

260

$2.51, \mathrm{p}=0.03$ ) were independent predictors of advanced liver fibrosis. The BsmI, Tru9I, ApaI, and TaqI genotypes, and the bAt (CCA) haplotype were not associated with advanced liver fibrosis.

\section{DISCUSSION}

The main findings are that the FokI rs2228570 TT/TC genotypes are independently associated with an increased risk of advanced liver fibrosis in Thai chronic HCV patients. Additionally, the $V D R$ bAt (CCA) haplotype was independently associated with poor response to PEG-IFN and ribavirin in patients with chronic HCV infection. Interestingly, these associations did not depend on the unfavorable $I L 28 B$ rs12979860 CT/TT genotypes, HCV genotype, or pretreatment HCV viral load. This study provides evidence indicating the important effects of $V D R$ polymorphisms on clinical outcomes in patients with chronic HCV infection.

VDR acts as a ligand-induced transcription factor that binds to 1, 25-dihydroxyVD and exerts its effects by regulating the expression of $>900$ genes in target tissues (Kato 2000). Recent studies have indicated that 1,25-dihydroxyVD and VDR are important regulators of both the innate and adaptive immune response (Khammissa et al. 2018; Rosen et al. 2012). VDR is expressed in almost all immune cells including B cells, activated T lymphocytes, neutrophils, natural killer cells, and antigen-presenting cells (Bhalla et al. 1983; Provvedini et al. 1983). The 1, 25-dihydroxyVD/VDR signaling pathway can activate monocytes, inhibit lymphocyte proliferation, and prevent the differentiation of dendritic cell precursors into antigen-presenting cells (Berer et al. 2000). In addition, 1, 25-dihydroxyVD is able to suppress $I F N-\gamma$ transcription via the binding of VDR to a silencer region in the $I F N-\gamma$ gene promoter (Saggese et al. 1989). Genetic variations of the $V D R$ gene can result in a dysfunctional receptor that subsequently affects the function of VD. VDR polymorphisms have been implicated in susceptibility to a variety of autoimmune diseases and cancers in a genome-wide association study and meta-analysis (Raimondi et al. 2009; Ramagopalan et al. 2010). Interestingly, VDR variants regulate the biological effects of VD independently of the serum 1, 25-dihydroxyVD level (Khammissa et al. 2018).

Regarding the association between VDR and response to PEG-IFN-based therapy in chronic HCV infection, a recent in vitro study reported that 1, 25-dihydroxyVD promotes the inhibitory effect of IFN- $\alpha$ on HCV replication by enhancing the expression of IFN-stimulated genes (ISGs) [39]. The crosstalk between VDR and IFN- $\alpha$ signaling may help to better understand the underlying mechanisms in clinical studies of HCV infection. The results from the current study showed that the VDR bAt (CCA) haplotype was associated with poor response to PEG-IFN-based therapy in Thai patients with chronic HCV infection. Although this association has been reported in several previous studies, the findings have been conflicting. Baur et al. and García-Martín et al. reported that Caucasian patients with chronic HCV infection with the bAt (CCA) haplotype had an impaired response to PEG-IFN and ribavirin [23, 25]. In contrast, Hung et al. did not find an association between the bAt (CCA) haplotype and antiviral response to PEG-IFN therapy in 139 Taiwanese patients with chronic HCV genotype-1 infection [22]. The possible reason for the discordant results between the two studies in Asian chronic HCV patients (i.e., our study and the Hung et al. study) may be the lower prevalence of the bAt haplotype in the previous study (54.7\%)

Peer) reviewing PDF | (2019:04:37052:1:1:NEW 26 Jul 2019) 
261

262

263

264

265

266

267

268

269

270

271

272

273

274

275

276

277

278

279

280

281

282

283

284

285

286

287

288

289

290

291

292

293

294

295

296

297

298

299

300

301

compared to that in our study $(87.7 \%)$. The mechanism underlying the association between the bAt (CCA) haplotype and poor response to PEG-IFN is still unclear. It may be due to the effect of the haplotype on the immune response-related IFN signaling cascade [36], as we found no relationship between the bAt (CCA) haplotype and pre-treatment HCV RNA level or liver fibrosis stage. Additionally, our study did not find any relationships between the VDR SNPs and the response to PEG-IFN-based therapy. In contrast, previous studies reported negative associations between the response to PEG-IFN-based therapy and both the FokI T allele [23, 40, 41] and the TaqI G allele [41] in patients with chronic HCV infection.

With regard to the relationship between $V D R$ polymorphisms and clinical outcomes, an in vitro analysis showed that VDR ligands inhibited transforming growth factor (TGF)- $\beta 1$-induced hepatic stellate cell activation and reduced liver fibrosis, while, in a mouse model, genetic knockout of VDR expression led to spontaneous liver fibrosis (Ding et al. 2013). The response of human hepatic stellate cells to TGF- $\beta 1$ and VD partially depends on the VDR polymorphisms (Beilfuss et al. 2015). In patients with chronic HCV genotype 1 infection, low serum VD level is related to severe liver fibrosis (Petta et al. 2010). VDR is expressed in hepatic parenchymal and inflammatory cells of patients with chronic HCV infection, and low VDR expression is associated with high portal inflammation (Barchetta et al. 2012). The current study showed that the VDR FokI rs $2228570 \mathrm{TT} / \mathrm{TC}$ genotypes and age $\geq 55$ years were independent risk factors for advanced liver fibrosis in Thai patients with chronic HCV infection. The BsmI, Tru9I, ApaI, and TaqI polymorphisms, and the bAt (CCA) haplotype, were not associated with advanced liver fibrosis or pre-treatment HCV RNA level in our cohort. Previous research reported that $V D R$ variants were related to decreased $\mathrm{HCV}$ infection susceptibility in a Chinese population (Wu et al. 2016). A cohort study of Swiss chronic HCV patients showed the bAt (CCA) haplotype was associated with rapid fibrosis progression and cirrhosis (Baur et al. 2012a). Additionally, BsmI and TaqI polymorphisms were associated with liver fibrosis in a Brazilian cohort (Scalioni et al. 2018). Moreover, in Taiwanese patients with chronic HCV infection, the bAt (CCA) haplotype, ApaI CC genotype, and TaqI AA genotype were associated with increased HCV RNA levels compared to other genotypes/haplotypes (Hung et al. 2016). Furthermore, the ApaI CC genotype was an independent factor for the development of HCC in a Taiwanese cohort with chronic HCV infection (Hung et al. 2014).

The FokI polymorphism restriction site is located in exon 2 in the $5^{\prime}$ coding region of VDR. This polymorphism leads to a $\mathrm{T}>\mathrm{C}$ (threonine to cysteine) substitution and the generation of a protein shortened by three amino acids, which makes the protein less functionally active than the wild type (van Etten et al. 2007). This polymorphism has been implicated in the response to PEGIFN therapy and several chronic liver diseases including autoimmune hepatitis and HCC in patients with chronic HBV infection (Mostafa-Hedeab et al. 2018; Vogel et al. 2002; Yao et al. 2013). The present study found an association between the FokI polymorphism and advanced liver fibrosis in patients with chronic HCV infection. The FokI polymorphism genotypic frequencies in a healthy Thai population have been reported to be $15.7 \%$ for $\mathrm{TT}, 43.6 \%$ for $\mathrm{TC}$, and $40.7 \%$ for $\mathrm{CC}$ (Sangkaew et al. 2018). These frequencies are consistent with the frequencies in our study of $20.9 \%$ for TT, $48.9 \%$ for TC, and $30.2 \%$ for CC in Thai patients with chronic HCV infection.

PeerJ reviewing PDF | (2019:04:37052:1:1:NEW 26 Jul 2019) 
Our study had several limitations. First, we did not investigate the relationship between the baseline serum VD level and response to PEG-IFN-based therapy because it is influenced by many confounding factors such as sunlight exposure, nutritional status, and liver function. In addition, $V D R$ variants can modulate their effects independently of serum VD status (Uitterlinden et al. 2004). Second, our study was a retrospective study, and pre-treatment serum samples were not collected for most of the participants. However, we still attempted to assess associations between the $V D R$ variants and clinical outcomes in patients with chronic HCV infection. Third, the combination of HCV infection with either alcoholic liver disease or non-alcoholic liver disease (NAFLD) could accelerate the progression of liver fibrosis, but we did not exclude patients with alcoholic liver disease or NAFLD. However, to identify independent associations between the studied polymorphisms and advanced fibrosis in chronic HCV patients, we used a stepwise multivariate analysis to adjust for confounding factors such as alcohol consumption, body mass index, and type 2 diabetes.

\section{CONCLUSIONS}

The present study demonstrates an association between the $V D R$ bAt (CCA) haplotype and poor response to PEG-IFN plus ribavirin therapy and associations between the VDR FokI rs2228570 TT/TC genotypes and advanced liver fibrosis in Thai patients with chronic HCV infection. These results provide helpful clinical information for understanding the causative effects of $V D R$ polymorphisms on clinical outcomes. Further studies are required to elucidate the detailed molecular mechanisms.

\section{ACKNOWLEDGEMENTS}

We would like to thank the staff of the Division of Gastroenterology and Hepatology (Chulalongkorn University), Center of Excellence in Liver Diseases, King Chulalongkorn Memorial Hospital, Thai Red Cross Society), Liver Fibrosis and Cirrhosis Research Unit (Chulalongkorn University), and the Center of Excellence in Clinical Virology (Chulalongkorn University) for their technical assistance and clinical support.

\section{ADDITIONAL INFORMATION AND DECLARATIONS}

\section{Funding}

The study was supported by the Ratchadaphiseksomphot Endowment Fund of the Hepatic Fibrosis and Cirrhosis Research Unit, Chulalongkorn University (GRU 6105530009-1). There was no additional external funding received for this study

\section{Conflict of Interest}

The authors declare there are no competing interests. 
335

336

337

338

339

340

341

342

343

344

345

346

347

348

349

350

351

352

353

354

355

356

357

358

359

360

361

362

57

\section{Author Contributions}

- Kessarin Thanapirom conceived and designed the experiments, analyzed the data, prepared figures and tables, authored and reviewed drafts of the paper, and approved the final draft.

- Sirinporn Suksawatamnuay performed the experiments, analyzed the data, and approved the final draft.

- Wattana Sukeepaisarnjaroen recruited patients, contributed reagents/materials/analysis tools and approved the final draft.

- Pisit Tangkijvanich recruited patients, contributed reagents/materials/analysis tools and approved the final draft.

- Panarat Thaimai performed the experiments and approved the final draft.

- Rujipat Wasitthankasem performed the experiments and approved the final draft.

- Yong Poovorawan contributed reagents/materials/analysis tools, authored and reviewed drafts of the paper, and approved the final draft.

- Piyawat Komolmit conceived and designed the experiments, contributed reagents/materials/analysis tools, prepared figures and tables, authored and reviewed drafts of the paper, and approved the final draft.

\section{Data Availability}

The raw data files are available in Supplemental Files: VDR1

\section{Supplemental Information}

4

5




\section{References}

Arteh J, Narra S, and Nair S. 2010. Prevalence of vitamin D deficiency in chronic liver disease. Dig Dis Sci 55:2624-2628. 10.1007/s10620-009-1069-9

Barchetta I, Carotti S, Labbadia G, Gentilucci UV, Muda AO, Angelico F, Silecchia G, Leonetti F, Fraioli A, Picardi A, Morini S, and Cavallo MG. 2012. Liver vitamin D receptor, CYP2R1, and CYP27A1 expression: relationship with liver histology and vitamin D3 levels in patients with nonalcoholic steatohepatitis or hepatitis $\mathrm{C}$ virus. Hepatology 56:2180-2187. 10.1002/hep.25930

Baur K, Mertens JC, Schmitt J, Iwata R, Stieger B, Eloranta JJ, Frei P, Stickel F, Dill MT, Seifert B, Ferrari HA, von Eckardstein A, Bochud PY, Mullhaupt B, Geier A, and Swiss Hepatitis CCSG. 2012a. Combined effect of 25-OH vitamin D plasma levels and genetic vitamin D receptor (NR 1I1) variants on fibrosis progression rate in HCV patients. Liver Int 32:635-643. 10.1111/j.1478-3231.2011.02674.x

Baur K, Mertens JC, Schmitt J, Iwata R, Stieger B, Frei P, Seifert B, Bischoff Ferrari HA, von Eckardstein A, Mullhaupt B, Geier A, and Swiss Hepatitis CCSG. 2012b. The vitamin D receptor gene bAt (CCA) haplotype impairs the response to pegylatedinterferon/ribavirin-based therapy in chronic hepatitis C patients. Antivir Ther 17:541547. 10.3851/IMP2018

Beilfuss A, Sowa JP, Sydor S, Beste M, Bechmann LP, Schlattjan M, Syn WK, Wedemeyer I, Mathe Z, Jochum C, Gerken G, Gieseler RK, and Canbay A. 2015. Vitamin D counteracts fibrogenic TGF-beta signalling in human hepatic stellate cells both receptordependently and independently. Gut 64:791-799. 10.1136/gutjnl-2014-307024

Berer A, Stock1 J, Majdic O, Wagner T, Kollars M, Lechner K, Geissler K, and Oehler L. 2000. 1,25-Dihydroxyvitamin $\mathrm{D}(3)$ inhibits dendritic cell differentiation and maturation in vitro. Exp Hematol 28:575-583.

Bhalla AK, Amento EP, Clemens TL, Holick MF, and Krane SM. 1983. Specific high-affinity receptors for 1,25-dihydroxyvitamin D3 in human peripheral blood mononuclear cells: presence in monocytes and induction in T lymphocytes following activation. $J$ Clin Endocrinol Metab 57:1308-1310. 10.1210/jcem-57-6-1308

Dadabhai AS, Saberi B, Lobner K, Shinohara RT, and Mullin GE. 2017. Influence of vitamin D on liver fibrosis in chronic hepatitis $\mathrm{C}$ : A systematic review and meta-analysis of the pooled clinical trials data. World J Hepatol 9:278-287. 10.4254/wjh.v9.i5.278

Deeb KK, Trump DL, and Johnson CS. 2007. Vitamin D signalling pathways in cancer: potential for anticancer therapeutics. Nat Rev Cancer 7:684-700. nrc2196 [pii]

10.1038/nrc2196 [doi]

Ding N, Yu RT, Subramaniam N, Sherman MH, Wilson C, Rao R, Leblanc M, Coulter S, He M, Scott C, Lau SL, Atkins AR, Barish GD, Gunton JE, Liddle C, Downes M, and Evans RM. 2013. A vitamin D receptor/SMAD genomic circuit gates hepatic fibrotic response. Cell 153:601-613. 10.1016/j.cell.2013.03.028

European Association for the Study of the L. 2011. EASL Clinical Practice Guidelines: management of hepatitis C virus infection. J Hepatol 55:245-264. 10.1016/j.jhep.2011.02.023

Feskanich D, Ma J, Fuchs CS, Kirkner GJ, Hankinson SE, Hollis BW, and Giovannucci EL. 2004. Plasma vitamin D metabolites and risk of colorectal cancer in women. Cancer Epidemiol Biomarkers Prev 13:1502-1508. 
408

409

410

411

412

413

414

415

416

417

418

419

420

421

422

423

424

425

426

427

428

429

430

431

432

433

434

435

436

437

438

439

440

441

442

443

444

445

446

447

448

449

450

451

452

453

Garcia-Alvarez M, Pineda-Tenor D, Jimenez-Sousa MA, Fernandez-Rodriguez A, GuzmanFulgencio M, and Resino S. 2014. Relationship of vitamin D status with advanced liver fibrosis and response to hepatitis C virus therapy: a meta-analysis. Hepatology 60:15411550. 10.1002/hep. 27281

Garcia-Martin E, Agundez JA, Maestro ML, Suarez A, Vidaurreta M, Martinez C, FernandezPerez C, Ortega L, and Ladero JM. 2013. Influence of vitamin D-related gene polymorphisms (CYP27B and VDR) on the response to interferon/ribavirin therapy in chronic hepatitis C. PLoS One 8:e74764. 10.1371/journal.pone.0074764

Ghany MG, Strader DB, Thomas DL, Seeff LB, and American Association for the Study of Liver D. 2009. Diagnosis, management, and treatment of hepatitis C: an update.

Hepatology 49:1335-1374. 10.1002/hep.22759

Giovannucci E, Liu Y, Rimm EB, Hollis BW, Fuchs CS, Stampfer MJ, and Willett WC. 2006. Prospective study of predictors of vitamin D status and cancer incidence and mortality in men. J Natl Cancer Inst 98:451-459. 10.1093/jnci/djj101

Holick MF. 2007. Vitamin D deficiency. N Engl J Med 357:266-281. 357/3/266 [pii]

10.1056/NEJMra070553 [doi]

Hung CH, Chiu YC, Hu TH, Chen CH, Lu SN, Huang CM, Wang JH, and Lee CM. 2014. Significance of vitamin d receptor gene polymorphisms for risk of hepatocellular carcinoma in chronic hepatitis C. Transl Oncol 7:503-507. 10.1016/j.tranon.2014.05.001

Hung CH, Hu TH, Lu SN, Chen CH, Wang JH, and Lee CM. 2016. Association of vitamin D receptor gene polymorphisms with response to peginterferon plus ribavirin in Asian patients with chronic hepatitis C. J Formos Med Assoc 115:278-283. 10.1016/j.jfma.2015.11.008

Jayasekera CR, Barry M, Roberts LR, and Nguyen MH. 2014. Treating hepatitis C in lowerincome countries. $N$ Engl J Med 370:1869-1871. 10.1056/NEJMp1400160

Kato S. 2000. The function of vitamin D receptor in vitamin D action. J Biochem 127:717-722.

Keane JT, Elangovan H, Stokes RA, and Gunton JE. 2018. Vitamin D and the Liver-Correlation or Cause? Nutrients 10. 10.3390/nu10040496

Khammissa RAG, Fourie J, Motswaledi MH, Ballyram R, Lemmer J, and Feller L. 2018. The Biological Activities of Vitamin D and Its Receptor in Relation to Calcium and Bone Homeostasis, Cancer, Immune and Cardiovascular Systems, Skin Biology, and Oral Health. Biomed Res Int 2018:9276380. 10.1155/2018/9276380

Mohd Hanafiah K, Groeger J, Flaxman AD, and Wiersma ST. 2013. Global epidemiology of hepatitis $\mathrm{C}$ virus infection: new estimates of age-specific antibody to $\mathrm{HCV}$ seroprevalence. Hepatology 57:1333-1342. 10.1002/hep.26141

Mostafa-Hedeab G, Sabry D, Abdelaziz GM, Ewaiss M, Adli N, and Fathy W. 2018. Influence of Vitamin D Receptor Gene Polymorphisms on Response to Pegylated Interferon in Chronic Hepatitis B Egyptian Patients. Rep Biochem Mol Biol 6:186-196.

Munger KL, Levin LI, Hollis BW, Howard NS, and Ascherio A. 2006. Serum 25hydroxyvitamin D levels and risk of multiple sclerosis. JAMA 296:2832-2838. 10.1001/jama.296.23.2832

Omata M, Kanda T, Wei L, Yu ML, Chuang WL, Ibrahim A, Lesmana CR, Sollano J, Kumar M, Jindal A, Sharma BC, Hamid SS, Dokmeci AK, Mamun Al M, McCaughan GW, Wasim J, Crawford DH, Kao JH, Yokosuka O, Lau GK, and Sarin SK. 2016. APASL consensus statements and recommendation on treatment of hepatitis C. Hepatol Int 10:702-726. 10.1007/s12072-016-9717-6

Peer) reviewing PDF | (2019:04:37052:1:1:NEW 26 Jul 2019) 
454

455

456

457

458

459

460

461

462

463

464

465

466

467

468

469

470

471

472

473

474

475

476

477

478

479

480

481

482

483

484

485

486

487

488

489

490

491

492

493

494

495

496

497

498

499

Penna G, Roncari A, Amuchastegui S, Daniel KC, Berti E, Colonna M, and Adorini L. 2005. Expression of the inhibitory receptor ILT3 on dendritic cells is dispensable for induction of CD4+Foxp3+ regulatory T cells by 1,25-dihydroxyvitamin D3. Blood 106:3490-3497. 10.1182/blood-2005-05-2044

Petta S, Camma C, Scazzone C, Tripodo C, Di Marco V, Bono A, Cabibi D, Licata G, Porcasi R, Marchesini G, and Craxi A. 2010. Low vitamin D serum level is related to severe fibrosis and low responsiveness to interferon-based therapy in genotype 1 chronic hepatitis $\mathrm{C}$. Hepatology 51:1158-1167. 10.1002/hep.23489 [doi]

Provvedini DM, Tsoukas CD, Deftos LJ, and Manolagas SC. 1983. 1,25-dihydroxyvitamin D3 receptors in human leukocytes. Science 221:1181-1183.

Raimondi S, Johansson H, Maisonneuve P, and Gandini S. 2009. Review and meta-analysis on vitamin D receptor polymorphisms and cancer risk. Carcinogenesis 30:1170-1180. 10.1093/carcin/bgp103

Ramagopalan SV, Heger A, Berlanga AJ, Maugeri NJ, Lincoln MR, Burrell A, Handunnetthi L, Handel AE, Disanto G, Orton SM, Watson CT, Morahan JM, Giovannoni G, Ponting CP, Ebers GC, and Knight JC. 2010. A ChIP-seq defined genome-wide map of vitamin D receptor binding: associations with disease and evolution. Genome Res 20:1352-1360. $10.1101 /$ gr. 107920.110

Rosen CJ, Adams JS, Bikle DD, Black DM, Demay MB, Manson JE, Murad MH, and Kovacs CS. 2012. The nonskeletal effects of vitamin D: an Endocrine Society scientific statement. Endocr Rev 33:456-492. 10.1210/er.2012-1000

Saggese G, Federico G, Balestri M, and Toniolo A. 1989. Calcitriol inhibits the PHA-induced production of IL-2 and IFN-gamma and the proliferation of human peripheral blood leukocytes while enhancing the surface expression of HLA class II molecules. $J$ Endocrinol Invest 12:329-335.

Sangkaew B, Nuinoon M, and Jeenduang N. 2018. Association of vitamin D receptor gene polymorphisms with serum $25(\mathrm{OH}) \mathrm{D}$ levels and metabolic syndrome in Thai population. Gene 659:59-66. 10.1016/j.gene.2018.03.047

Scalioni LP, Santos BRD, Spritzer PM, Villela-Nogueira CA, Laura Lewis-Ximenez L, PolloFlores P, Bordalo Cathala Esberard E, Brandao-Mello CE, Lampe E, and Villar LM. 2018. Impact of vitamin D receptor and binding protein gene polymorphisms in clinical and laboratory data of HCV patients: Cross sectional study. Medicine (Baltimore) 97:e9881. 10.1097/MD.0000000000009881

Shaker O, Nassar Y, Ayoub S, Elrazki M, and Zahra A. 2016. Impact of FokI (rs10735810) and BsmI (rs1544410) on Treatment of Chronic HCV Patients With Genotype 4. J Clin Lab Anal 30:1021-1027. 10.1002/jcla.21974

Uitterlinden AG, Fang Y, Van Meurs JB, Pols HA, and Van Leeuwen JP. 2004. Genetics and biology of vitamin D receptor polymorphisms. Gene 338:143-156. 10.1016/j.gene.2004.05.014

Vallet-Pichard A, Mallet V, Nalpas B, Verkarre V, Nalpas A, Dhalluin-Venier V, Fontaine H, and Pol S. 2007. FIB-4: an inexpensive and accurate marker of fibrosis in HCV infection. comparison with liver biopsy and fibrotest. Hepatology 46:32-36. 10.1002/hep.21669

van Etten E, Verlinden L, Giulietti A, Ramos-Lopez E, Branisteanu DD, Ferreira GB, Overbergh L, Verstuyf A, Bouillon R, Roep BO, Badenhoop K, and Mathieu C. 2007. The vitamin D receptor gene FokI polymorphism: functional impact on the immune system. Eur $J$ Immunol 37:395-405. 10.1002/eji.200636043

Peer) reviewing PDF | (2019:04:37052:1:1:NEW 26 Jul 2019) 
500

501

502

503

504

505

506

507

508

509

510

511

512

513

514

515

516

517

518

519

520

521

522

523

524

525

526

527

528

529

530

531
Villar LM, Del Campo JA, Ranchal I, Lampe E, and Romero-Gomez M. 2013. Association between vitamin $\mathrm{D}$ and hepatitis $\mathrm{C}$ virus infection: a meta-analysis. World $J$ Gastroenterol 19:5917-5924. 10.3748/wjg.v19.i35.5917

Vogel A, Strassburg CP, and Manns MP. 2002. Genetic association of vitamin D receptor polymorphisms with primary biliary cirrhosis and autoimmune hepatitis. Hepatology 35:126-131. 10.1053/jhep.2002.30084

von Essen MR, Kongsbak M, Schjerling P, Olgaard K, Odum N, and Geisler C. 2010. Vitamin D controls $\mathrm{T}$ cell antigen receptor signaling and activation of human T cells. Nat Immunol 11:344-349. 10.1038/ni.1851

WHO. 2017. WHO. Global hepatitis report. Available from: http://wwwwhoint/hepatitis/publications/global-hepatitis-report2017/en/.

Wu M, Yue M, Huang P, Zhang Y, Xie C, Yu R, Li J, and Wang J. 2016. Vitamin D level and vitamin $\mathrm{D}$ receptor genetic variations contribute to $\mathrm{HCV}$ infection susceptibility and chronicity in a Chinese population. Infect Genet Evol 41:146-152. 10.1016/j.meegid.2016.03.032

Yao X, Zeng H, Zhang G, Zhou W, Yan Q, Dai L, and Wang X. 2013. The associated ion between the VDR gene polymorphisms and susceptibility to hepatocellular carcinoma and the clinicopathological features in subjects infected with HBV. Biomed Res Int 2013:953974. 10.1155/2013/953974

Zoulim F, Liang TJ, Gerbes AL, Aghemo A, Deuffic-Burban S, Dusheiko G, Fried MW, Pol S, Rockstroh JK, Terrault NA, and Wiktor S. 2015. Hepatitis C virus treatment in the real world: optimising treatment and access to therapies. Gut 64:1824-1833. 10.1136/gutjnl2015-310421 


\section{Table $\mathbf{1}$ (on next page)}

Baseline patient characteristics according to response to PEG-IFN-based therapy 
1 Table 1: Baseline patient characteristics according to response to PEG-IFN2 based therapy

\begin{tabular}{|l|l|l|l|}
\hline & $\begin{array}{l}\text { Non-SVR } \\
(\mathbf{n = 2 2 0})\end{array}$ & SVR (n=334) & p-value \\
\hline Female, n (\%) & $71(32.3 \%)$ & $118(35.3 \%)$ & 0.46 \\
\hline Age (years), mean \pm SD & $52.1 \pm 8.0$ & $50.1 \pm 9.8$ & 0.01 \\
\hline $\begin{array}{l}\text { Body mass index }\left(\mathrm{kg} / \mathrm{m}^{2}\right), \text { mean } \\
\pm \text { SD }\end{array}$ & $24.6 \pm 3.4$ & $24.6 \pm 3.6$ & 0.96 \\
\hline Alcohol drinking, n (\%) & $134(69.8 \%)$ & $142(61.7 \%)$ & 0.1 \\
\hline Diabetes Mellitus, n (\%) & $51(26.2 \%)$ & $53(22.7 \%)$ & 0.41 \\
\hline Genotype, n (\%) & & & \\
\hline 1 & $122(55.5 \%)$ & $133(39.8 \%)$ & $<0.001$ \\
\hline 2 & 0 & $1(0.3 \%)$ & \\
\hline 3 & $85(38.6 \%)$ & $160(47.9 \%)$ & \\
\hline 6 & $13(5.9 \%)$ & $40(12 \%)$ & \\
\hline $\begin{array}{l}\text { HCV RNA (log IU/ml), mean } \pm \\
\text { SD }\end{array}$ & $6.05 \pm 0.61$ & $5.8 \pm 0.8$ & 0.002 \\
\hline ALT (U/L), mean \pm SD & $107.5 \pm 166.5$ & $100.1 \pm 74.0$ & 0.49 \\
\hline Advanced liver fibrosis, n (\%) & $82(41.2 \%)$ & $94(30.6 \%)$ & 0.02 \\
\hline IL28B rs12979860, n (\%) & & & $<0.001$ \\
\hline CC & $148(67.3 \%)$ & $290(86.8 \%)$ & \\
\hline CT & $69(31.4 \%)$ & $38(11.4 \%)$ & $6(1.8 \%)$ \\
\hline TT & $3(1.4 \%)$ & & \\
\hline
\end{tabular}




\section{Table 2 (on next page)}

Frequencies of the VDR genotypes and the bAt haplotype in Thai patients with chronic hepatitis $C$ infection treated with PEG-IFN. 
1 Table 2: Frequencies of the $V D R$ genotypes and the bAt haplotype in Thai 2 patients with chronic hepatitis $C$ infection treated with PEG-IFN.

\begin{tabular}{|c|c|c|c|c|c|}
\hline & $\begin{array}{l}\text { All patients } \\
(\mathrm{n}=554)\end{array}$ & $\begin{array}{l}\text { Non-SVR } \\
(n=220)\end{array}$ & $\operatorname{SVR}(n=334)$ & $\begin{array}{l}\text { Odds ratio } \\
(95 \% \mathrm{CI})\end{array}$ & $\begin{array}{l}\mathrm{p}- \\
\text { value }\end{array}$ \\
\hline \multicolumn{6}{|l|}{$\begin{array}{l}\text { FokI } \\
\text { rs2228570 }\end{array}$} \\
\hline TT & $116(20.9 \%)$ & $51(23.2 \%)$ & $65(19.5 \%)$ & $\begin{array}{ll}0.80 & (0.53- \\
1.21) & \end{array}$ & 0.29 \\
\hline $\mathrm{TC}$ & $271(48.9 \%)$ & $105(47.7 \%)$ & $166(49.7 \%)$ & & \\
\hline $\mathrm{CC}$ & $167(30.2 \%)$ & $64(29.1 \%)$ & $103(30.8 \%)$ & & \\
\hline \multicolumn{6}{|l|}{$\begin{array}{l}\text { BsmI } \\
\text { rs } 1544410\end{array}$} \\
\hline$C C$ & $453(81.8 \%)$ & $181(82.3 \%)$ & $272(81.4 \%)$ & $\begin{array}{ll}0.95 & (0.61- \\
1.47) & \end{array}$ & 0.80 \\
\hline $\mathrm{CT}$ & $94(17.0 \%)$ & $36(16.4 \%)$ & $58(17.4 \%)$ & & \\
\hline TT & $7(1.3 \%)$ & $3(1.4 \%)$ & $4(1.2 \%)$ & & \\
\hline \multicolumn{6}{|l|}{$\begin{array}{l}\text { Tru9I } \\
\text { rs757343 }\end{array}$} \\
\hline GG & $326(58.8 \%)$ & $136(61.8 \%)$ & $190(56.9 \%)$ & $\begin{array}{l}0.82 \\
1.15)\end{array}$ & 0.25 \\
\hline GA & $197(35.6 \%)$ & $74(33.6 \%)$ & $123(36.8 \%)$ & & \\
\hline AA & $31(5.6 \%)$ & $10(4.5 \%)$ & $21(6.3 \%)$ & & \\
\hline \multicolumn{6}{|l|}{$\begin{array}{l}\text { ApaI } \\
\text { rs7975232 }\end{array}$} \\
\hline $\mathrm{CC}$ & $252(45.5 \%)$ & $106(48.2 \%)$ & $146(43.7 \%)$ & $\begin{array}{ll}0.84 & (0.59- \\
1.18) & \\
\end{array}$ & 0.30 \\
\hline $\mathrm{CA}$ & $240(43.3 \%)$ & $95(43.2 \%)$ & $145(43.4 \%)$ & & \\
\hline AA & $62(11.2 \%)$ & $19(8.6 \%)$ & $43(12.9 \%)$ & & \\
\hline \multicolumn{6}{|l|}{$\begin{array}{l}\text { TaqI } \\
\text { rs731236 }\end{array}$} \\
\hline AA & $477(86.1 \%)$ & $197(89.5 \%)$ & $280(83.8 \%)$ & $\begin{array}{ll}0.61 \\
1.02)\end{array}$ & 0.06 \\
\hline $\mathrm{AG}$ & $68(12.3 \%)$ & $23(10.5 \%)$ & $45(13.5 \%)$ & & \\
\hline
\end{tabular}




\begin{tabular}{|c|l|l|l|ll|l|}
\hline GG & $9(1.6 \%)$ & 0 & $9(2.7 \%)$ & & \\
\hline $\begin{array}{l}\text { bAt (CCA) } \\
\text { haplotype }\end{array}$ & $486(87.7 \%)$ & $201(91.4 \%)$ & $285(85.3 \%)$ & $\begin{array}{l}1.82 \\
3.18)\end{array}$ & $(1.04-$ & 0.03 \\
\hline
\end{tabular}

4

5

6

7

8

9

10

11

12

13

14

15

16

17

18

19

20

21

22

23

24

25

26 


\section{Table 3(on next page)}

Baseline characteristics, virological factors and liver fibrosis stage in accordance to the bAt (CCA) haplotype. 
1 Table 3: Univariate and multivariate regression analyses of factors associated 2 with poor response to pegylated interferon-based therapy in patients with 3 chronic HCV infection.

\begin{tabular}{|l|l|l|l|l|}
\hline & \multicolumn{2}{|l|}{ Univariate analysis } & \multicolumn{2}{l|}{ Multivariate analysis } \\
\hline & OR (95\%CI) & p-value & OR (95\%CI) & p-value \\
\hline Female & $0.87(0.61-1.25)$ & 0.46 & & \\
\hline Age & $1.02(1.00-1.04)$ & 0.01 & $1.02(0.99-1.00)$ & 0.11 \\
\hline Body mass index & $1.00(0.95-1.06)$ & 0.97 & & \\
\hline Alcohol drinking & $1.43(0.95-2.15)$ & 0.1 & & \\
\hline $\begin{array}{l}\text { Diabetes } \\
\text { Mellitus }\end{array}$ & $1.20(0.77-1.87)$ & 0.41 & & \\
\hline Genotype 1 & $1.89(1.33-2.66)$ & $<0.001$ & $1.59(1.07-2.37)$ & 0.02 \\
\hline $\begin{array}{l}\text { HCV RNA (log } \\
\text { IU/ml) }\end{array}$ & $1.47(1.15-1.88)$ & 0.002 & $1.73(1.31-2.28)$ & $<0.001$ \\
\hline ALT (U/L) & $1.00(0.99-1.00)$ & 0.50 & & $1.68(1.10-2.58)$ \\
\hline $\begin{array}{l}\text { Advanced liver } \\
\text { fibrosis }\end{array}$ & $1.59(1.10-2.30)$ & 0.02 & 0.02 \\
\hline $\begin{array}{l}\text { IL28B } \\
\text { rs12979860 } \\
\text { CT/TT }\end{array}$ & $3.21(2.10-4.90)$ & $<0.001$ & $3.44(2.12-5.58)$ & $<0.001$ \\
\hline bAt haplotype & $1.82(1.04-3.18)$ & 0.03 & $2.02(1.04-3.91)$ & 0.03 \\
\hline
\end{tabular}




\section{Table 4 (on next page)}

Baseline characteristics, virological factors and liver fibrosis stage in accordance to the bAt (CCA) haplotype. 
1 Table 4: Baseline characteristics, virological factors and liver fibrosis stage in 2 accordance to the bAt (CCA) haplotype.

\begin{tabular}{|l|l|l|l|}
\hline & $\begin{array}{l}\text { CCA haplotype } \\
(\mathrm{n}=486)\end{array}$ & $\begin{array}{l}\text { Other } \\
\text { haplotypes } \\
(\mathrm{n}=68)\end{array}$ & $\begin{array}{l}\mathrm{p}- \\
\text { value }\end{array}$ \\
\hline $\begin{array}{l}\text { Pre-treatment HCV RNA level }(\log \\
\text { IU/ml), mean } \pm \text { SD }\end{array}$ & $5.93 \pm 0.77$ & $5.87 \pm 0.69$ & 0.57 \\
\hline Pre-treatment ALT, mean \pm SD & $97.3 \pm 68.0$ & $143.5 \pm 285.9$ & 0.004 \\
\hline Advanced liver fibrosis, n (\%) & $158(35.5 \%)$ & $18(29.5 \%)$ & 0.36 \\
\hline Rapid virological response, $\mathrm{n}(\%)$ & $257(65.6 \%)$ & $37(71.2 \%)$ & 0.42 \\
\hline Early virological response, $\mathrm{n}(\%)$ & $371(88.8 \%)$ & $48(87.3 \%)$ & 0.75 \\
\hline $\begin{array}{l}\text { IL28B rs12979860 CT/TT } \\
\text { genotypes, } \mathrm{n}(\%)\end{array}$ & $93(19.1 \%)$ & $23(33.8 \%)$ & 0.005 \\
\hline
\end{tabular}

3

4

5

6

7

8

9

10

11 


\section{Table 5 (on next page)}

Univariate and multivariate regression analyses of factors associated with advanced liver fibrosis in patients with chronic HCV infection. 
1 Table 5: Univariate and multivariate regression analyses of factors associated 2 with advanced liver fibrosis in patients with chronic $\mathrm{HCV}$ infection.

\begin{tabular}{|l|l|l|l|l|}
\hline & \multicolumn{2}{|l|}{ Univariate analysis } & \multicolumn{2}{l|}{ Multivariate analysis } \\
\hline & OR (95\%CI) & p-value & OR (95\%CI) & p-value \\
\hline Age $\geq 55$ years & $2.38(1.62-3.49)$ & $<0.001$ & $2.25(1.54-3.32)$ & $<0.001$ \\
\hline Female & $1.37(0.93-2.00)$ & 0.11 & & \\
\hline Body mass index & $1.01(0.96-1.07)$ & 0.72 & & \\
\hline $\begin{array}{l}\text { Alcohol } \\
\text { consumption }\end{array}$ & $1.25(0.79-1.98)$ & 0.35 & & \\
\hline HCV genotype 1 & $0.75(0.52-1.09)$ & 0.75 & & \\
\hline $\begin{array}{l}\text { IL28B } \\
\text { rs12979860 } \\
\text { CT/TT } \\
\text { genotypes }\end{array}$ & $0.94(0.60-1.47)$ & 0.78 & & \\
\hline $\begin{array}{l}\text { FokI rs2228570 } \\
\text { TT/TC } \\
\text { genotypes }\end{array}$ & $1.81(1.18-2.75)$ & 0.006 & $1.63(1.06-2.51)$ & 0.03 \\
\hline $\begin{array}{l}\text { BsmI rs1544410 } \\
\text { GG genotype }\end{array}$ & $1.04(0.64-1.69)$ & 0.88 & & \\
\hline $\begin{array}{l}\text { Tru9l rs757343 } \\
\text { GG genotype }\end{array}$ & $1.00(0.69-1.45)$ & 1.00 & & \\
\hline $\begin{array}{l}\text { Apal rs7975232 } \\
\text { GG genotype }\end{array}$ & $0.90(0.62-1.30)$ & 0.57 & & \\
\hline $\begin{array}{l}\text { TaqI rs731236 } \\
\text { TT genotype }\end{array}$ & $0.90(0.52-1.54)$ & 0.70 & & \\
\hline $\begin{array}{l}\text { bAt (CCA) } \\
\text { haplotype }\end{array}$ & $1.32(0.73-2.36)$ & 0.36 & & \\
\hline
\end{tabular}


Figure 1

Association between advanced liver fibrosis and VDR polymorphisms in patients with chronic HCV infection.

$<$ !--[if !supportLists]--> <!--[if !supportLists]-->A) <!--[endif]-->FokI rs2228570 T>C, B)

Bsml rs1544410 C>T, C) Tru9I rs757343 G>A, D) Apal rs7975232 C>A, E) Taql rs731236 A>G

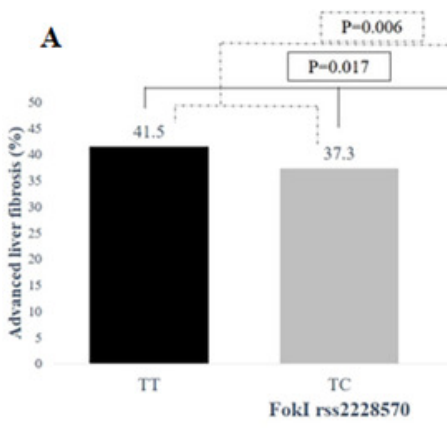

B

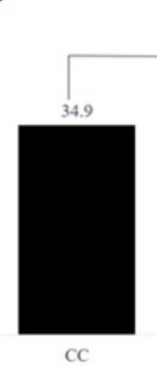

$\mathrm{cc}$

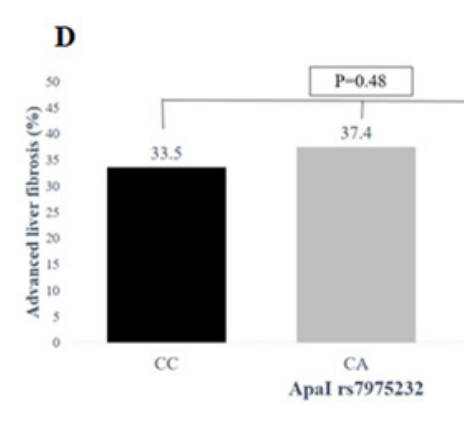

CC
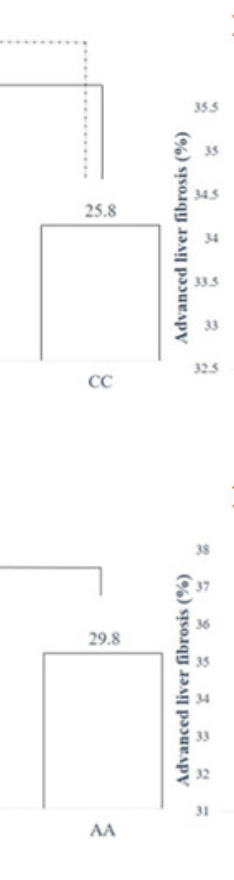

E

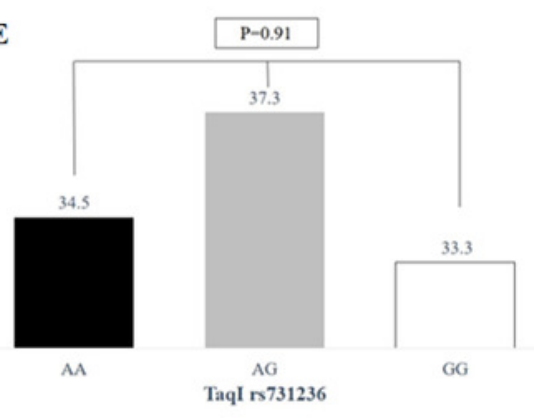

C

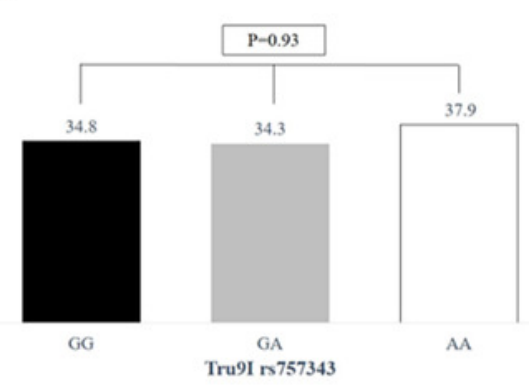


Figure 2

Baseline serum HCV RNA according to VDR polymorphisms in patients with chronic HCV infection

\section{A) Fokl rs2228570 T>C, B) Bsml rs1544410 C>T, C) Tru9I rs757343 G>A, D) Apal} rs7975232 C>A, E) Taql rs731236 A>G

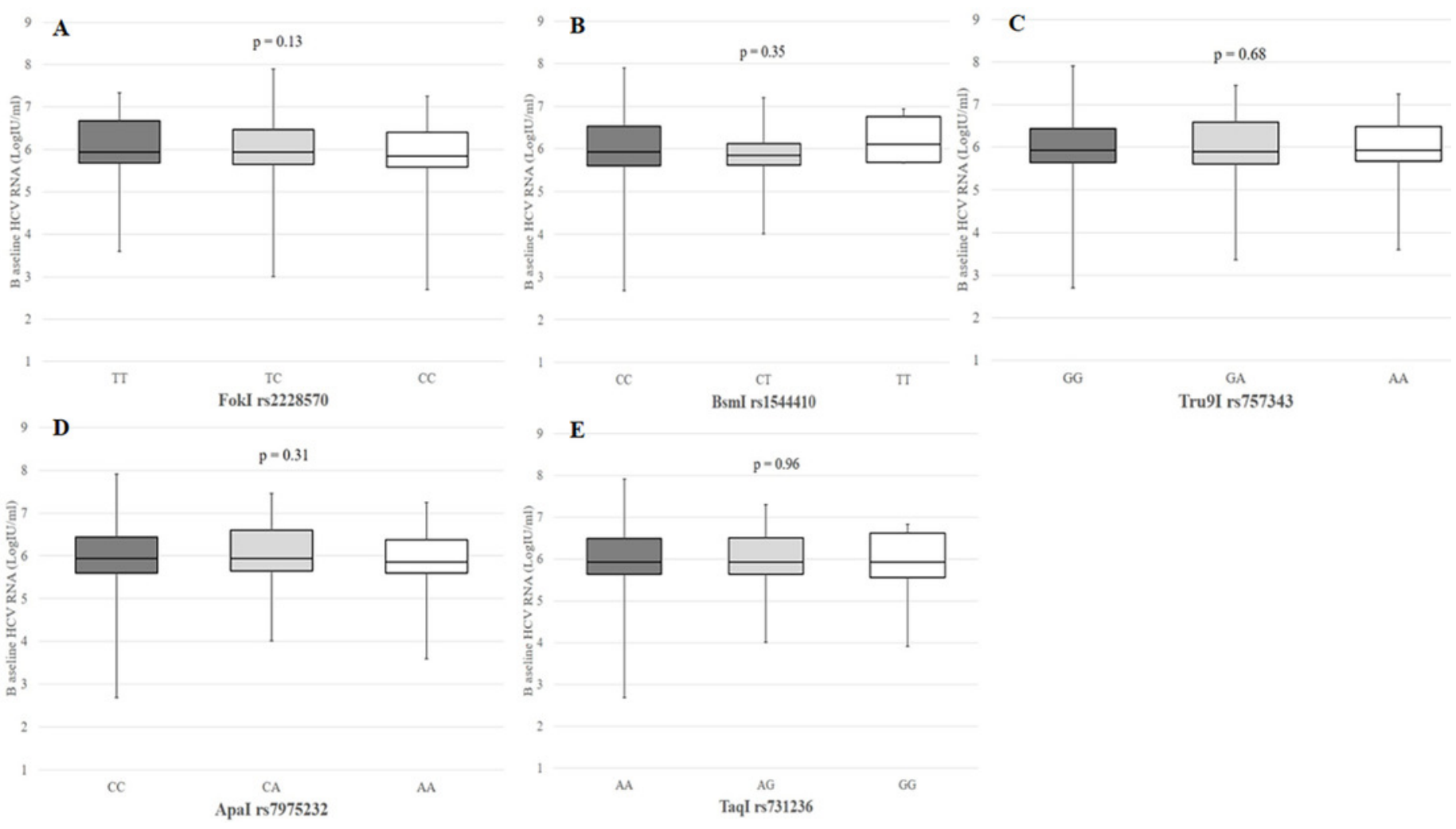

